\title{
The role of university environment in promoting entrepreneurial behavior: evidence from heterogeneous regions in Brazil
}

\author{
Anne Kathleen Lopes da Rocha, \\ Gustavo Hermínio Salati Marcondes de Moraes and Bruno Fischer \\ School of Applied Sciences, University of Campinas, \\ Limeira, Brazil
}

\begin{abstract}
Purpose - The purpose of this study is to evaluate the microfoundations of student entrepreneurship, a cornerstone of innovation ecosystems. To this end, this paper assesses how perceived university support for entrepreneurship influences entrepreneurial characteristics and intentions in students enrolled at Amazonas and São Paulo State Universities.

Design/methodology/approach - A quantitative approach based on multivariate data analysis using confirmatory factor analysis and structural equation modeling was applied to a sample of 420 respondents.

Findings - Results indicate that the university environment positively influences entrepreneurial behavior and intention in students. Nonetheless, further integration between academia and external dimensions of the ecosystems is necessary to drive more intense entrepreneurial activity in students. The educational contexts of Amazonas and São Paulo present significant differences in the relationship between entrepreneurial characteristics and entrepreneurial intention with a stronger influence found for Amazonas. This finding suggests a relative lack of propensity of students from São Paulo to engage in entrepreneurial venturing.

Research limitations/implications - The main limitations involve the use of non-probabilistic sampling procedures and students' heterogeneity in terms of academic seniority.

Practical implications - This research offers guidance for policies targeting the generation of entrepreneurial activity in universities embedded in developing countries' innovation ecosystems and facing distinct levels of socioeconomic development.

Originality/value - This research presents a novel analysis of the microfoundations driving student entrepreneurship within different educational contexts in a developing country. Results highlight the necessary conditions for universities to foster entrepreneurial activity and, incidentally, feed innovation ecosystems with entrepreneurial talent.
\end{abstract}

Keywords Innovation ecosystems, University, Entrepreneurial intention, Entrepreneurial characteristics,

Student entrepreneurship, Brazil, Structural equation modeling

Paper type Research paper

(C) Anne Kathleen Lopes da Rocha, Gustavo Hermínio Salati Marcondes de Moraes and Bruno Fischer. Published in Innovation \& Management Review. Published by Emerald Publishing Limited. This article is published under the Creative Commons Attribution (CC BY 4.0) licence. Anyone may reproduce, distribute, translate and create derivative works of this article (for both commercial and non-commercial purposes), subject to full attribution to the original publication and authors. The full terms of this licence maybe seen at http://creativecommons.org/licences/by/4.0/legalcode

This study was financed in part by the Coordenação de Aperfeiçoamento de Pessoal de Nível Superior - Brasil (CAPES) - Finance Code 001.

The authors thank Espaço da Escrita - Pró-Reitoria de Pesquisa - UNICAMP - for the language services provided (para trabalhos em co-autoria).

Received 21 August 2020 Revised 4 January 2021 Accepted 27 January 2021 
INMR

19,1

\section{Introduction}

Davidsson (2016, p. 629) defines entrepreneurship as "the (attempted) creation of new economic activity." As a research field, this "focuses on novelty and is based on nonlinear thinking" (Landström \& Harirchi, 2018, p. 19), serving as a tool for solving societal and economic problems. It "takes place in a community of interdependent actors, individuals, entities and regulatory bodies within a given geographic area" (Cavallo, Ghezzi, \& Balocco, 2019, p. 1300). In this respect, universities can be deemed as pivotal elements in driving entrepreneurial activity, functioning as a source of new ideas and inventions, thus feeding innovation ecosystems with talent and technology (Abreu \& Grinevich, 2013). A critical aspect of such dynamics concerns how the academic environment can - directly or indirectly - influence students' perceptions on entrepreneurship as a potential career path (Fayolle \& Liñán, 2014; Fischer, Moraes, \& Schaeffer, 2019a).

Over the past two decades, universities have been expected to integrate academia and the productive system (Moraes, Fischer, Campos, \& Schaeffer, 2020), to act, not only as human capital providers but also as active agents in the commercialization of scientific knowledge and as seedbeds for the emergence of new firms (Politis, Winborg, \& Dahlstrand, 2012). In this vein, academic institutions must evolve from the traditional focus on education and research to promote regional development and economic growth through innovation (Alves, Fischer, Schaeffer, \& Queiroz, 2019a). Concrete mechanisms include entrepreneurial education (Politis et al., 2012), incubator facilities and other holding environments that offer an adequate atmosphere for students to explore and exploit new ideas (Moraes et al., 2020) and organizational support for reaching out to other influential dimensions of innovation ecosystems (Alves et al., 2019a). Envisioned outcomes involve the dawning of entrepreneurial mindsets and the consequent emergence of new ventures (Blasi \& Sedita, 2020; Politis et al., 2012).

Accordingly, the way through which universities stimulate entrepreneurial engagement is mainly associated with how these institutions shape students' attitudes and behavior toward entrepreneurship (Moraes, lizuka, \& Pedro, 2018; Politis et al., 2012; Saeed, Yousafzai, YaniDe-Soriano, \& Muffatto, 2015). Furthermore, individuals may also be driven toward entrepreneurship because of behavioral characteristics, such as self-confidence, risk-taking ability and locus of control (Turker \& Selcuk, 2009). Previous assessments find that, on top of context, behavioral aspects are determinant to entrepreneurship (Caliendo \& Kritikos, 2011), as they enable the entrepreneur to venture forth even after having achieved success. Entrepreneurial intention plays a crucial role in this process. According to Vodă and Florea (2019), entrepreneurial intention can be perceived as the antecedent of entrepreneurial behavior, as it deals with "predisposition or motivation to become an entrepreneur" (Saeed et al., 2015, p. 1131).

Prior literature contains extant assessments linking entrepreneurial intention and university support (Bignotti \& Le Roux, 2016; Trivedi, 2016), entrepreneurial intention and behavioral characteristics (Moraes et al., 2018; Vodă \& Florea, 2019), as well as university support and behavioral characteristics (Saeed et al., 2015). However, the methodological robustness of previous studies on entrepreneurial attitude, intention or action needs further examination (Bignotti \& Le Roux, 2016). Additionally, student entrepreneurship is an under-investigated phenomenon, with limited knowledge available about the extent to which student entrepreneurs are socialized into a certain way of thinking and behaving in relation to their start-up processes (Moraes et al., 2020; Politis et al., 2012) Scholars have also mainly focused on large urban centers located in developed countries (Jena, 2020; Mack \& Mayer, 2016; Roundy, 2017; Spigel, 2017). Acs, Autio, and Szerb (2014) have demonstrated the impact of different local factors with high levels of entrepreneurship, thus warranting the need to explore this phenomenon in ecosystems facing different maturity stages. 
Furthermore, only a few approaches have had a specific group of study for analysis, such as undergraduate students from specific fields of knowledge (Fischer et al., 2019a) or from specific states of a developing country (Wibowo, Purwana, Wibowo, \& Saptono, 2019). Hence, fundamental gaps remain regarding the relation of university support with entrepreneurial characteristics and intention (Alves et al., 2019a), the role of students in an entrepreneurial context (Blasi \& Sedita, 2020; Matt \& Schaeffer, 2018), as well as the ability of universities to set the appropriate conditions for entrepreneurship in developing countries (Fischer et al., 2019a; Schaeffer, Fischer, \& Queiroz, 2018). In turn, while these micro-processes that permeate the evolution of innovation ecosystems are critical to understand the dynamics of new firm formation, they remain largely uncharted by dedicated literature. As a result, most initiatives concerning student entrepreneurship in developing countries try to emulate frameworks applied in developed markets without explicitly considering potential heterogeneities in terms of ecosystems' characteristics and maturity stages.

Drawing from this background, we identify a relatively untested opportunity to evaluate whether the university environment influences behavioral aspects related to student entrepreneurship. From a practical standpoint, graduate students play a major role in the initial establishment of academic spin-off companies and the development, growth and reconfiguration of spin-offs (Blasi \& Sedita, 2020; Hayter, Lubynsky, \& Maroulis, 2017). Thus, by focusing on the perception of Business Administration (BA) students, it is possible to identify more effective and systematic ways of promoting entrepreneurship in universities and, consequently, contribute to society with the placement or creation of new ventures (Matt \& Schaeffer, 2018). Furthermore, the local nature of innovation ecosystems is characterized by economic, institutional, legal, cultural, social and political factors that affect individuals' inclination toward entrepreneurship (Hayter et al., 2017; Matt \& Schaeffer, 2018).

Hence, taking Brazil as a relevant case for entrepreneurship research (Alves et al., 2019a), this study can contribute to this discussion by broadening the knowledge about university environment and characteristics related to entrepreneurship, considering BA students' perspectives in different contexts (Amazonas and São Paulo). Based on these arguments, this article proposes the following research questions:

$R Q 1$. What is the university environment's impact on entrepreneurial characteristics and intention of students?

$R Q 2$.Are there differences in these relationships when distinct innovation ecosystems' contexts are assessed?

Results indicate that the university environment positively influences entrepreneurial behavior and intention in students. Nonetheless, further integration between academia and external dimensions of the ecosystems is still needed to drive more intense entrepreneurial activity in students. The educational contexts of Amazonas and São Paulo presented significant differences in the relationship between entrepreneurial characteristics and entrepreneurial intention, in which a higher influence was found in Amazonas. This finding suggests a relative lack of propensity of students from São Paulo to engage in starting new ventures. Analytical implications encompass the identification of key drivers for improving academic environments in terms of promoting an entrepreneurial culture within the ecosystems in which they are embedded.

The article is structured as follows. After these introductory arguments, Section 2 articulates the literature on entrepreneurship drivers. Brazil's socioeconomic diverse scenario is also taken under consideration. From this literature review, we derive our guiding hypotheses. Section 3 presents the research methodology and data collection

\section{Role of university environment}


INMR

19,1

procedures. Section 4 reports the description and analysis of empirical results. Section 5 presents the discussion and conclusions with final remarks, implications and avenues for future research.

\section{Entrepreneurship drivers}

Entrepreneurship studies usually center around individuals. However, these same individuals are often influenced and shaped by the nature of opportunities (Alves et al., 2019a). Among such drivers, our focus is delimited to: university environment, entrepreneurial behavior and Brazil's socioeconomic context.

\subsection{University environment}

Universities are complex organizations, composed of many elements that when combined can translate their attitudes toward entrepreneurship, such as demonstrated for the case of the University of Strasbourg in France (Matt \& Schaeffer, 2018). They are fundamentally-based around three core missions (Alves et al., 2019a), namely, education, research and activities related to innovation, social change and industrial competitiveness (Moraes et al., 2018; Ozaralli \& Rivenburgh, 2016). The university environment itself can support students through creating an atmosphere conducive to entrepreneurship, which is crucial for understanding student's perceptions of the university support, an aspect that has been demonstrated for the case both of developing and developed countries (Mustafa, Hernandez, Mahon, \& Chee, 2016; Politis et al., 2012). According to Saeed et al. (2015) and Trivedi (2016), these are the types of perceived university support for entrepreneurship:

- Perceived educational support (PES): refers to the traditional role of the university in which the focus is on knowledge, skills, internship and networking opportunities given to students enabling them to start a new venture.

- Perceived concept development support (PCDS): refers to universities' support in business development of ideas, the knowledge required to start a new business and introductions to entrepreneurial role models. It deals with the process of transforming ideas into workable concepts.

- Perceived business development support (PBDS): refers to financial arrangements given to students for new venture creation and the provision of support networks. For instance: seed-funding or incubation facilities, connection to influential people and assistance in knowledge transfer for commercialization purposes.

- Perceived entrepreneurial characteristics development support (PECDS): reflects one's innermost skills, abilities and thoughts on whether they have what is needed to perform a certain task successfully.

Broadly, student's interest in entrepreneurship is developed and instigated when executing all kinds of activities at the university environment, both inside and outside the classroom (Moraes et al., 2018; Mustafa et al., 2016). As such, when students consider universities as providers of an adequate preparation for them to start a new venture, the likelihood of entrepreneurial intention increases (Wibowo et al., 2019). Similarly, based on an analysis of engineering and business students in Brazil, Moraes et al. (2018) propose that the academic environment exercises great influence on entrepreneurial characteristics as it can be nurtured on students. Nevertheless, it cannot be suppressed that universities can fail to provide sufficient business knowledge and preparation, hence discouraging students from choosing an entrepreneurial career, as observed for the case 
of Pakistani universities (Saeed et al., 2015). These conditions place universities and their respective organizational practices and capabilities to offer a holding environment for prospective entrepreneurs (or lack thereof) as an important part of the ecosystemic puzzle.

\subsection{Entrepreneurial behavior: Entrepreneurial intention and characteristics}

Entrepreneurial intention is the connection between ideas and action. It is the state of mind that directs a person toward a specific goal (Saeed et al., 2015). Likewise, Ajzen (1991, p. 181) defined it as "the indication of how hard people are willing to try, of how much an effort they are planning to exert, to perform the behavior." Thus, the stronger the intention, the more likely an individual will engage in a given activity.

Intention-based models have already been tested and proven its adequacy in diverse scenarios (Moraes et al., 2018). In this sense, the entrepreneurial intention is considered as the first step into the process of venture creation, as the intention is not action per se, but rather a valuable predictor of behavior (Ajzen, 1991; Liñán \& Chen, 2009). Moreover, new business creation may be affected by many factors, such as innovative environments (Liñán \& Chen, 2009), knowledge, experience (Koe, Sa'ari, Majid, \& Ismail, 2012) and behavioral aspects (Saeed et al., 2015). Connecting these aspects to the expected influences exerted by the university environment (Klingbeil, Semrau, Ebers, \& Wilhelm, 2019), our first research hypothesis can be stated as:

H1.Perceived university support for entrepreneurship has a positive influence on undergraduate students' entrepreneurial intention.

When pondering about behavioral aspects, an individual with certain characteristics may be driven to entrepreneurship more likely than others, considering they are a "different breed of manager" because of their differential characteristics (Caliendo \& Kritikos, 2011, p. 1; Moraes et al., 2018). These characteristics comprise:

- Self-efficacy, the ability one has to organize and effectively execute actions.

- Risk-taking, the inclination one has to perform certain activities, considering all relevant variables to stop, change courses or sustain an entrepreneurial project.

- Planning, one's preparation for the future.

- Opportunity recognition, each individual's notions on how to distinguish highpotential from low-potential opportunities and to anticipate adversities.

- Persistency, ability to overcome several obstacles, make mistakes - and learn from them.

- Sociability, one's social capital.

- Innovation, ability to combine ideas, necessities and other demands in a creative manner.

- Leadership, ability to influence others to adopt one's goal voluntarily (Caliendo \& Kritikos, 2011; Moraes et al., 2018; Schmidt \& Bohnenberger, 2009).

In addition, behavior can be affected by contextual aspects, such as the organizational environment in which individuals are embedded (Ibarra \& Obodaru, 2016). Following this rationale, our second hypothesis can be defined as:

H2.Perceived university support for entrepreneurship has a positive influence on undergraduate students' entrepreneurial characteristics.
Role of
university
environment 
INMR

19,1

Complementarily, entrepreneurial characteristics have been previously related to entrepreneurial intention (Kusmintarti, Thoyib, Ashar, \& Maskie, 2014; Lüthje \& Franke, 2003) and have been recognized as one of the critical predictors to entrepreneurial intention (Wibowo et al., 2019). In consonance with this view, the global entrepreneurship Monitor (2017) report states that 53.6\% of Brazilians perceive having the knowledge and characteristics for starting a new business. Prior assessments of these dynamics in the academic context of European universities support these claims (Huyghe, Knockaert, \& Obschonka, 2016). Hence, our third research hypothesis is presented:

H3.Entrepreneurial characteristics have a positive influence on undergraduate students' entrepreneurial intentions.

\subsection{Ecosystems of entrepreneurship and innovation: the role of context}

Entrepreneurial activity is a socioeconomic phenomenon embedded in local contexts, whereas heterogeneous regions tend to present different propensities toward the emergence of new ventures (Brown \& Mason, 2017; Radosevic \& Yoruk, 2013). In fact, even successful regions present different trajectories toward structuring a thriving ecosystem of entrepreneurship and innovation (Chandler \& Saxenian, 1995). These dynamics put emphasis on relationships among complementary agents as the driving forces behind quantitative and qualitative trends involving rates of new firm formation (Auerswald \& Dani, 2017; Malerba \& McKelvey, 2020). Mason and Brown (2014, p. 5) formalize these propositions by defining these ecosystems as "a set of interconnected entrepreneurial actors, entrepreneurial organizations, institutions and entrepreneurial processes, which formally and informally coalesce to connect, mediate and govern the performance within the local entrepreneurial environment."

Following this reasoning, Stam and van de Ven (2019) observe that contextual elements and entrepreneurial micro-processes attached to individual behavior are intrinsically intertwined. In turn, this interplay among input and output elements is complex, involving high levels of endogeneity in causal paths (Alves, Fischer, Vonortas, \& Queiroz, 2019b; Godley, Morawetz, \& Soga, 2019; Spigel, 2017). As a result, while ecosystems of innovation and entrepreneurship present conceptual similarities, their respective trajectories and levels of success present stark differences - even within a single country (Fischer et al., 2019a). Hence, the inclusion of the ecosystem background becomes a relevant factor to understand individual-level entrepreneurial propensity, as outlined in our last set of hypotheses:

H4.Perceived university support for entrepreneurship, entrepreneurial intention and entrepreneurial characteristics differ in their relationship when considering distinct regional ecosystems of innovation and entrepreneurship.

H4a.Perceived university support for entrepreneurship and entrepreneurial intention differs in its relationship when considering distinct regional ecosystems of innovation and entrepreneurship.

H4b.Perceived university support for entrepreneurship and entrepreneurial characteristics differ in its relationship when considering distinct regional ecosystems of innovation and entrepreneurship.

$H 4 c$.Entrepreneurial characteristics and entrepreneurial intention differ in its relationship when considering distinct regional ecosystems of innovation and entrepreneurship. 


\section{Methodological approach}

This study used partial least squares-structural equation modeling (PLS-SEM), a statistical model used for examining the prediction and explanation of the constructs. It also provides a common point between path modeling and confirmatory factor analysis (CFA). Thus, it is adequate to comprehend the relationship among university environment, entrepreneurial intention and entrepreneurial characteristics (Hair, Hult, Ringle, \& Sarstedt, 2017).

Another motive to use PLS-SEM is that this model presents reflexive and formative indicators. It is formulated with two hierarchical latent variables, where entrepreneurial characteristics and university environment are second-order constructs (high order constructs) constituted by first-order constructs (low order constructs) (Hair, Sarstedt, Ringle, \& Gudergan, 2018). To calculate and validate the statistical tests, the Software SmartPLS 3.0 M3 (Ringle, Wende, \& Becker, 2015) was used.

\subsection{Research settings}

Brazil is the largest country in Latin America and the sixth-largest country in the world, with 8.46 million square kilometers and approximately 208 million habitants (IBGE, 2018). It also is a nation marked with socioeconomic differences across regions. On one hand, there is Amazonas, one of the 27 Brazilian federative units and the largest one by area (IBGE, 2018), which held the country's attention and was a synonym for prosperity for all immigrants during its Rubber Boom (Barham \& Coomes, 1994). After the downfall of the rubber industry in Brazil, Amazonas faced socioeconomic challenges that were partially solved by the creation of the Manaus Free Trade Zone (MFTZ) (SUDAM, 2020). Even though MFTZ has enabled the development of economic hubs, it has an expiration year (2073). On the other hand, there is São Paulo, the state with the highest gross domestic product (GDP) per capita in the country and the highest population density with over 45 million people. It also carries the best results at Basic Education Development while being the 12th largest state in the area (IBGE, 2018).

Amazonas and São Paulo are situated in two different regions (North and Southeast, respectively) and their comparison indicates Brazil's different contexts:

- Amazonas, an eccentric state that cannot fit into Brazil's pattern of high growth entrepreneurship.

- São Paulo, one of the most important metropolitan areas in the country (Fischer, Schaeffer, \& Queiroz, 2019b).

Overall, they represent extreme ends: economically, the North region only participated in $5.38 \%$ of Brazil's 2016 GDP while the Southeast contributed with $53.17 \%$; with São Paulo as the biggest contributor and Amazonas, the 16th contributor (SEDECTI, 2018). In terms of the educational systems, the same pattern can be seen. Where 25\% of Brazil's 2,448 Education Organizations are concentrated in São Paulo, Amazonas presents less than 1\% of such organizations (INEP, 2017).

Therefore, the gaps and diversity among these ecosystems of entrepreneurship and innovation (São Paulo as a main economic hub, Amazonas as a peripheral system) can offer valuable insights on the differential micro-dynamics of entrepreneurship taking place in these highly dissimilar contexts. Accordingly, academic communities are composed by its attributes of diversity, and available assets, as well as the agents, institutions and processes that allow them to support the processes of entrepreneurial ecosystems, functioning as sources of ideas, manpower and entrepreneurs themselves, ultimately corroborating on the regional presence of skilled labor and knowledge (Fischer et al., 2019a; Miller \& Acs, 2017). Understanding how the student entrepreneurship phenomenon unfolds in distinct

Role of
university
environment 
INMR

19,1 ecosystemic environments is likely to offer relevant nuances of the entrepreneurial microprocesses that drive innovative endeavors.

\subsection{Sample and data}

A single cross-section survey was conducted between May 15th, 2019 and June 19th, 2019. The University of the State of Amazonas (UEA), the University of Campinas (UNICAMP) and the University of São Paulo (USP) were chosen to mirror the heterogeneous innovation ecosystems in which these institutions are embedded. UEA, founded in 2001, received the investment of 406m reais in 2018 from the State of Amazonas (SEDECTI, 2018; UEA, 2016). When considering the university's first mission (education) it offers 84 undergraduate courses, 16 master's degrees and $5 \mathrm{PhD}$ programs; looking into the university's second mission (research), registered at National Council for scientific and Technological Development (CNPq), UEA has 5 research groups, 0 journals and 12 research projects. Finally, observing the university's third mission (activities related to innovation, social change and industrial competitiveness), UEA has 1 business incubator and 17 academic administrations and centers (Alves et al., 2019a; CNPq, 2019; UEA, 2016).

In contrast, there are the São Paulo State Universities: UNICAMP was founded in 1966 and USP in 1934; combined they received over 7bn reais of investment in 2019 from the State's government (Secretaria da Fazenda e Planejamento - SP, 2019; UNICAMP, 2019; USP, 2019). Considering the missions: (CNPq, 2019; UNICAMP, 2019; USP, 2019) as its first mission, UNICAMP offers 66 undergraduate courses and 155 graduate programs; whereas USP offers 340 undergraduate courses and 264 graduate programs. Regarding the second mission: registered at CNPq, UNICAMP has 75 research groups, 4 journals and 297 research projects; USP has 162 research groups, 22 journals and 562 research projects. Related to their third mission: UNICAMP offers 1,279 certificate courses, holds 20 junior companies, 1 business incubator and 71 academic administrations and centers; whilst USP offers 902 certificate courses, holds 20 junior companies, 4 business incubators and 88 academic administrations and centers.

Previous studies focused on faculty members (Moraes et al., 2020) or students from science, technology, engineering and mathematics fields of expertise (Fischer et al., 2019a; Moraes et al., 2018), whereas this research focused on the business management field. Business management students constitute the largest group in Global University Entrepreneurial Spirit Students' Survey (GUESSS) Report's sample (24.7\% of all students) and in Brazilian undergraduate courses scenario (14.5\% of all courses), therein being the most representative field of expertise (INEP, 2017; Sieger, Fueglistaller, Zellweger, \& Braun, 2018). Hence, BA students were invited to participate on an anonymous basis and survey completion was voluntary. The non-probabilistic sample characterization information - age, gender, marital status, university, a major area of concentration and graduation year - was also collected. In total, 420 answers were gathered, being: 144 respondents from UEA, 191 from UNICAMP and 85 from USP. Out of the 420 respondents, $53 \%$ were female, $96 \%$ were single, on an average age of 22 years, $39 \%$ were senior students and $19 \%$ were juniors. The collection process involved $97 \%$ in person interviews and $3 \%$ online applications. This strategy was adopted to maximize response rates.

To evaluate the sample size and statistical power of the analysis, $G *$ Power 3.1 software (Faul, Erdfelder, Buchner, \& Lang, 2009) was used, based on the recommendations by Chin and Newsted (1999), Cohen (1988) and Hair et al. (2017). Considering eight predictors, a significance level of $5 \%$, a statistical power of 0.8 and an average effect size $\left(f^{2}=0.15\right.$, which is equivalent to $r^{2}=13 \%$ ), the minimum size of the sample required is 109 . As the 
final sample used comprised 420 students, it is suitable for estimation by PLS path modeling [1].

CFA was also conducted to measure and test all indicators in the same model and were restricted to load on their respective factor. Table 1 presents the constructs, the indicators of the measuring instrument, indicating its CFA and descriptive statistics. It should be noticed that the Entrepreneurial Intention and Entrepreneurial Characteristics constructs were built based on previous studies (De Noble, Jung, \& Ehrlich, 1999; Krakauer, Moraes, Coda, \& Berne, 2018; Liñán \& Chen, 2009; Markman \& Baron, 2003; Moraes et al., 2018; Rocha \& Freitas, 2014; Schmidt \& Bohnenberger, 2009), while the University Environment construct was adapted from Saeed et al. (2015), Fayolle and Liñán (2014) and Schwarz, Almer-Jarz, and Wdowiak (2006) studies to comply with Brazilian context. Following these scholars, Likert scales range from 1 (totally disagree) to 7 (totally agree).

Measures with factor loads higher than or equal to 0.7 and higher than 0.4 and lower than 0.7 are susceptible to be kept in the model (Hair et al., 2017). In this case, the impact of excluding these measures in the average variance extraction (AVE) and in composite reliability $(\mathrm{CR})$ was evaluated. The model excluded only the measures that could negatively affect AVE and CR (Hair et al., 2017). Thus, SE1, SE5, RT3, IN3, LI1, PE2 and SO3 indicators were excluded.

\section{Description and analysis of results}

The analysis of results is composed by the evaluation of: measurement scales, measurement model and structural model. The measurement model analysis at the first stage level considers 13 reflexive constructs. As seen in Table 2, all indicators are within established values, except Cronbach's alpha for some indicators. However, according to Hair et al. (2017), Cronbach's alpha is sensitive to the number of items on the scale and generally tends to underestimate internal consistency. Thus, it is more appropriate to perform the $\mathrm{CR}$ assessment, where the indicators presented adequate values. Also, the square root of the AVE is another indicator for discriminant validity between the constructs and all correlation values between latent variables are higher than the square root of the AVE (diagonal).

The measurement model analysis at the second stage level considers one reflexive construct (entrepreneurial intention) and two formative constructs (entrepreneurial characteristics and university environment). To assess entrepreneurial intention construct, Cronbach's alpha, CR and AVE were calculated and presented indicators within the established parameters (Hair et al., 2017). Additionally, for the formative constructs (entrepreneurial characteristics and university environment) convergent validity, multicollinearity analysis and significance and relevance were evaluated and presented adequate values (Hair et al., 2017).

Before evaluating the structural model, the variance inflation factor for each subsection of the structural model was analyzed and all values are within those established by Hair et al. (2017). The significance of indicators and student's $t$-test were also evaluated. Table 3 presents the values of coefficients between the constructs and their respective student's $t$-tests.

Results indicate that the relationships between entrepreneurial characteristics and entrepreneurial intention and between the university environment and entrepreneurial characteristics are significant, supporting $H 2$ and $H 3$. However, they also suggest that the university environment does not influence entrepreneurial intention - not supporting $H 1$ although previous studies show that this relationship exists (Koe et al., 2012; Saeed et al., 2015; Turker \& Selcuk, 2009; Wibowo et al., 2019). One possible explanation for this lack of 
INMR

19,1

48

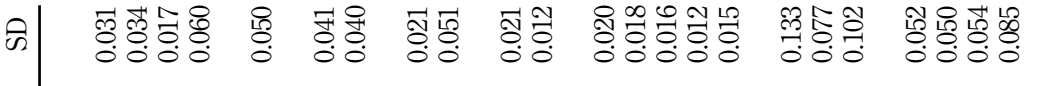

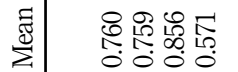

\%

路落

遌魚

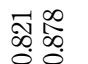

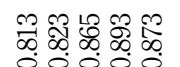

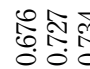

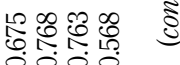

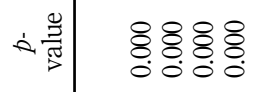

\%

혛음

ริㅎㅀㅇ

촣응

홍형형휴읍

좋졍음

0000

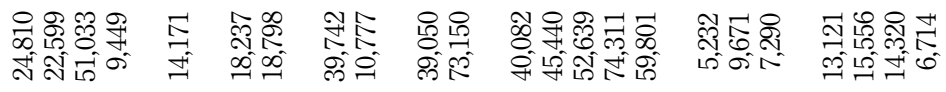

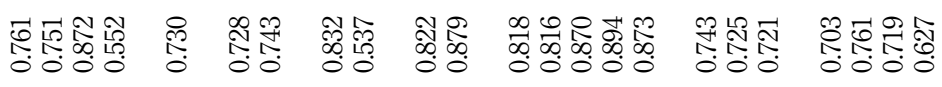

量部

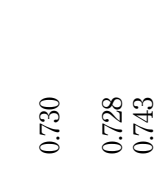

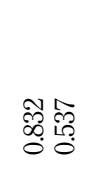

(1)
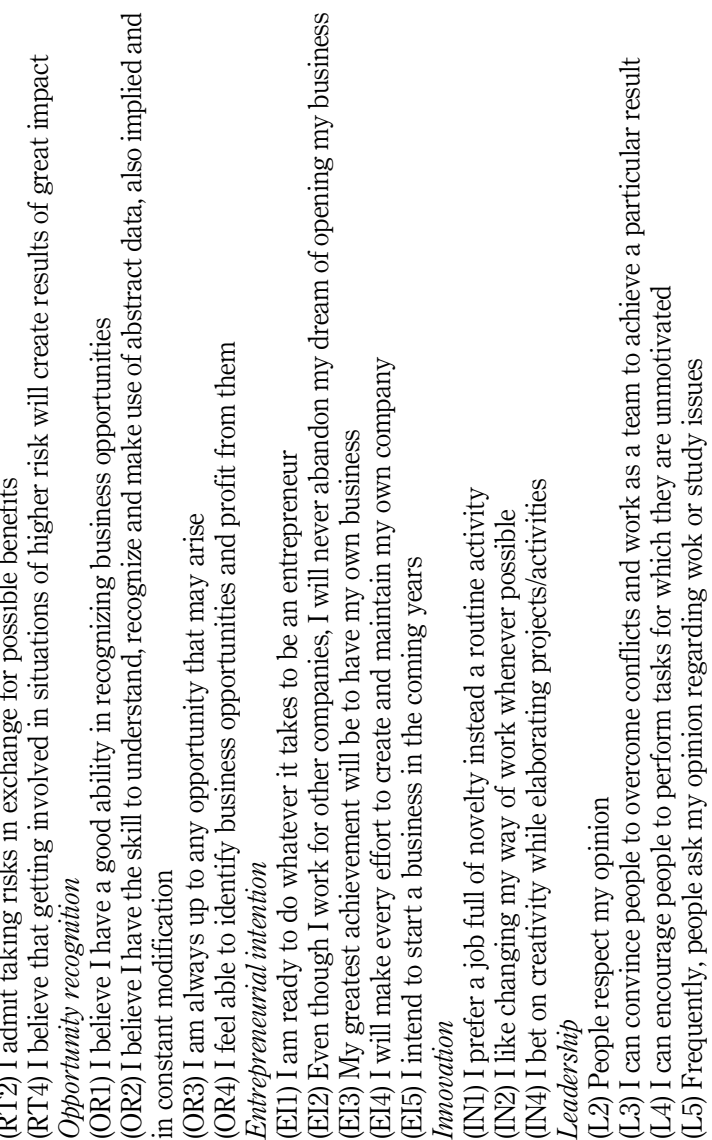

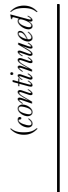




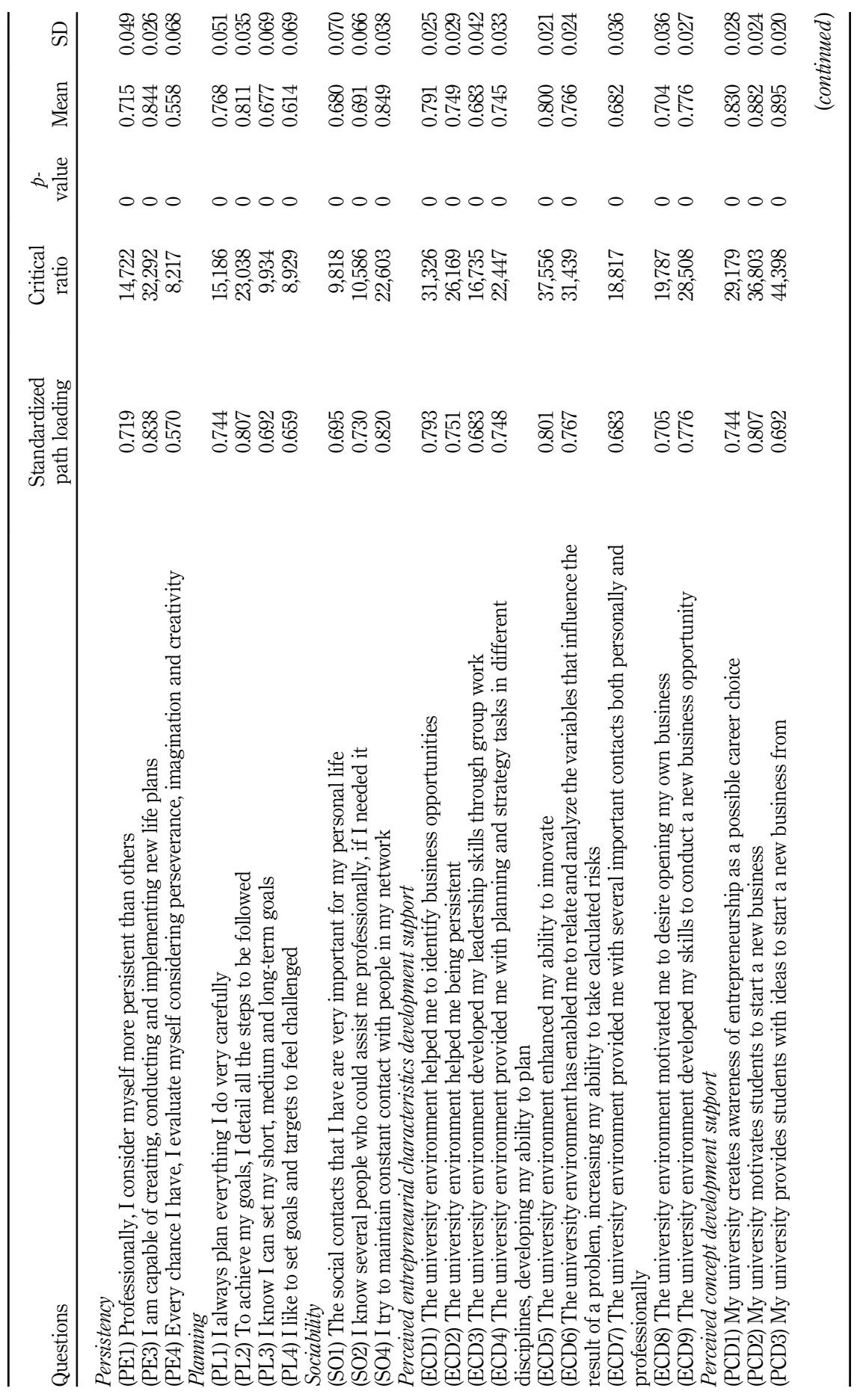




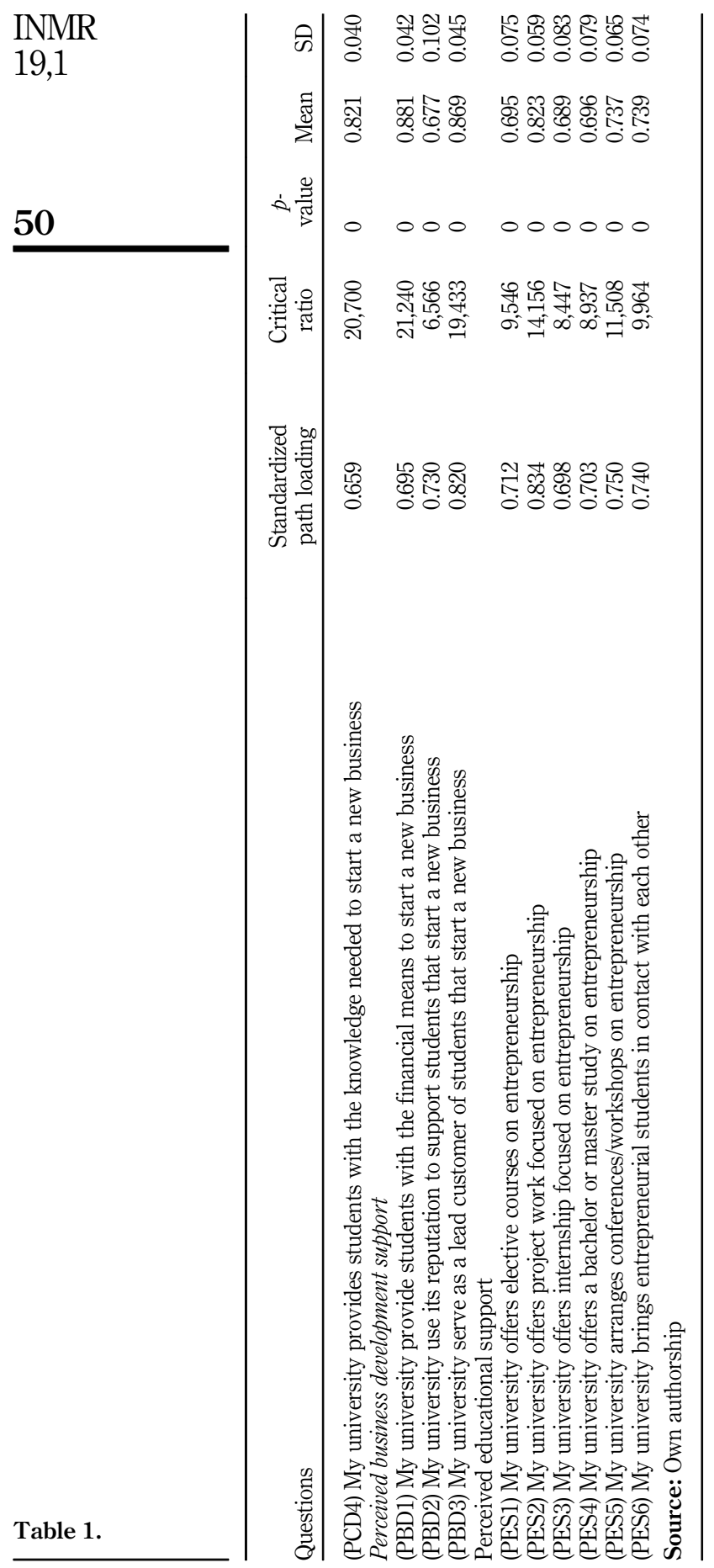




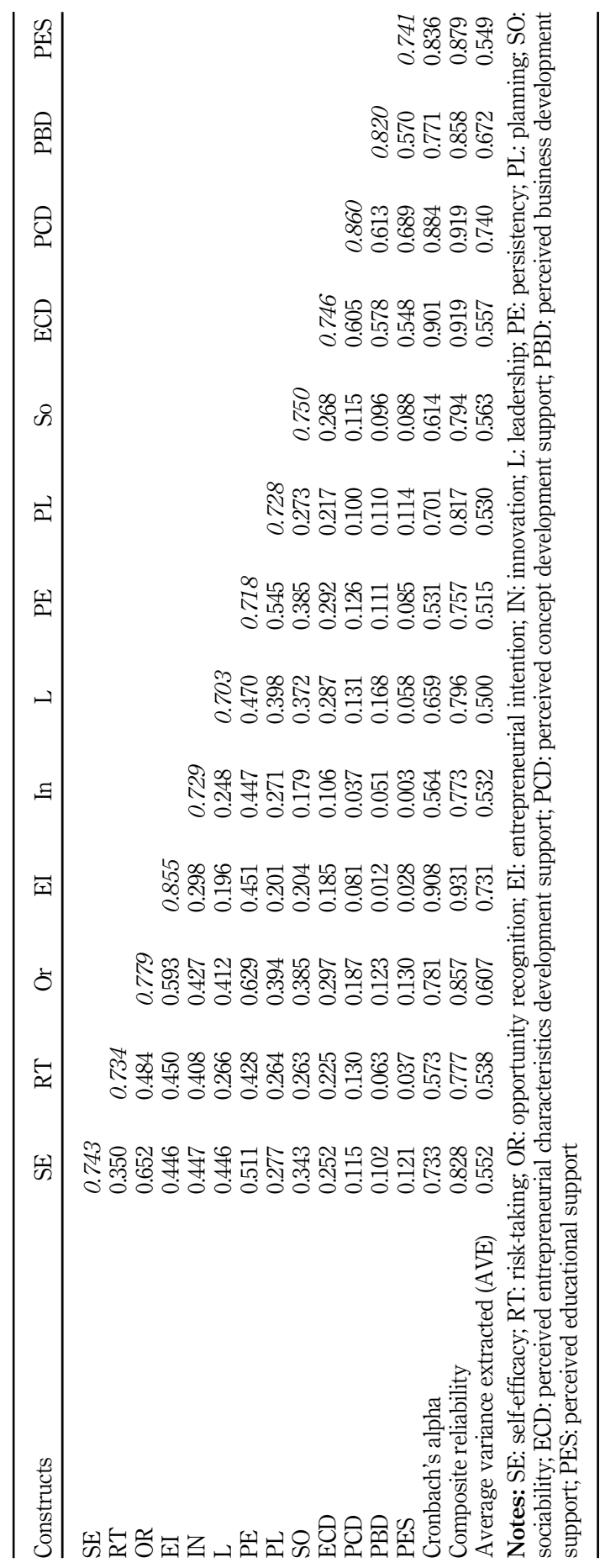


INMR

19,1

\section{2}

\section{Table 3}

Coefficients of the structural model between constructs

significance may be the presence of a full mediation relationship of entrepreneurial characteristics between the university environment and entrepreneurial intention. In fact, there is theoretical support for the full mediation of some entrepreneurial characteristics with other constructs (Zhao, Hills, \& Seibert, 2005).

In this case, it is recommended that relationships between the constructs to be recalculated without the presence of the mediating variable (Baron \& Kenny, 1986; Edwards \& Lambert, 2007). Thus, based on the possibility of a full mediation relationship by entrepreneurial characteristics, a new calculation was made without the presence of this relationship in the structural model and the values of the coefficients were adequate. From these results, it can be understood that the university environment is one of the factors that promote entrepreneurial intention, and that this association is mediated by entrepreneurial characteristics, thus not rejecting our first research hypothesis.

To evaluate the coefficient of determination $\left(R^{2}\right)$ we based our analysis on the studies of Cohen (1988) and Faul et al. (2009), which determine that $f^{2}$ values equal to $0.02,0.15$ and 0.35 are considered, respectively, as small, medium and large effects. According to the analyzes, the complete model presented an $R^{2}$ of 0.377 for the entrepreneurial intention construct, which is considered high; and an $R^{2}$ of 0.156 for the entrepreneurial characteristics construct. While for the full mediation model, the results of the entrepreneurial intention construct presented an $R^{2}$ of 0.066 and the entrepreneurial characteristics construct presented an $R^{2}$ of 0.204 . Also, for SEM models, values of $Q^{2}$ higher than zero indicate the predictive relevance of the path model. In the case of this study, the values are considered adequate (Hair et al., 2017).

To test if there are differences between the relationships according to the University's State, multi-group analysis were performed (Hair et al., 2018). Table 4 presents the analysis results of the constructs' significant relationships among groups of respondents from Amazonas and São Paulo universities.

Following results from estimations (Table 4), it is possible to affirm that there are significant differences in the relationships between the constructs depending on the state of the university. When considering the complete model, this difference lies in the relationship between entrepreneurial characteristics and entrepreneurial intention $(H 4 c)$; this effect is

\begin{tabular}{lcccc}
\hline Path & Sample & & & \\
mean & SD & $T$-statistics & $p$-values \\
\hline Entrepreneurial characteristics $\rightarrow$ entrepreneurial intention & 0.611 & 0.040 & 15.039 & 0.000 \\
University environment $\rightarrow$ entrepreneurial characteristics & 0.395 & 0.056 & 7.026 & 0.000 \\
University environment $\rightarrow$ entrepreneurial intention & 0.015 & 0.046 & 0.329 & 0.742 \\
\hline
\end{tabular}

\begin{tabular}{|c|c|c|}
\hline Path & $\begin{array}{c}\text { Path coefficients - difference (Amazonas } \\
\text { vs SP) }\end{array}$ & $\begin{array}{c}p- \\
\text { values }\end{array}$ \\
\hline
\end{tabular}

\section{Table 4}

Analysis of

relationships according to the state of the university
University environment $\rightarrow$ entrepreneurial

0.133

0.715

characteristics

University environment $\rightarrow$ entrepreneurial intention

Entrepreneurial characteristics $\rightarrow$ entrepreneurial intention
0.080

0.160

0.789

0.029 
more strongly positive at the Amazonas university than at the São Paulo universities. Hence, $H 4 a$ and $H 4 b$ are not supported.

The complete model resulting from our empirical approach is presented in Figure 1.

The synthesis of this study hypotheses tests is shown in Table 5.

\section{Role of university environment}

\section{Discussion and conclusions}

Universities stand for a pivotal part of local innovation ecosystems characterized by specific settings, such as economic, cultural, social and political factors (Matt \& Schaeffer, 2018). As such, this research focused on exploring the role of the university environment on behavioral aspects related to entrepreneurship, through analyzing its effect on entrepreneurial characteristics and intention of UEA, UNICAMP and USP BA students. This approach offers a novel perspective on the micro-processes that drive evolutionary dynamics within the context of innovation ecosystems by looking into the fundamental drivers of academic entrepreneurship - a source of entrepreneurial activity that can sustain and trigger aggregate competitiveness over time.

Results confirmed the positive influence of perceived university support for entrepreneurship and entrepreneurial characteristics on entrepreneurial intention. This result corroborates with findings of previous studies between perceived university support and entrepreneurial intention in both developed and developing countries' contexts (Asimakopoulos, Hernández, \& Peña Miguel, 2019; Saeed et al., 2015), as well as perceived university support and entrepreneurial characteristics (Mustafa et al., 2016; Rocha \& Freitas, 2014; Vodă \& Florea, 2019). Entrepreneurial characteristics presented a full

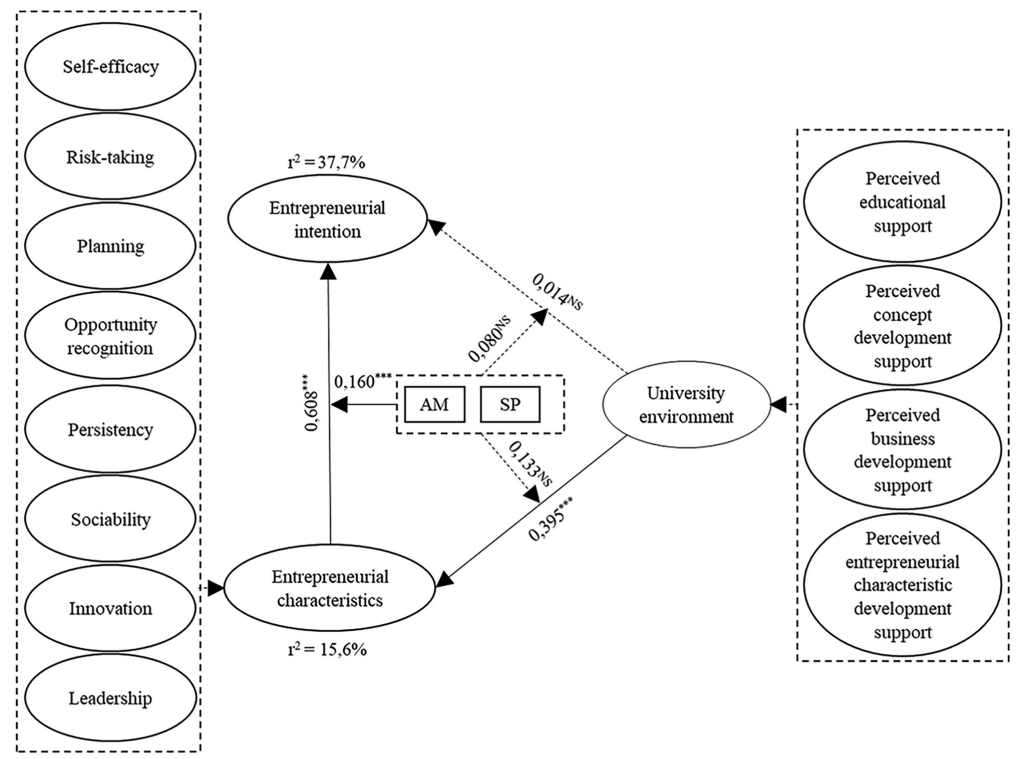

Note: $*=$ significant at $5 \% ; * *=$ significant at $1 \% ; * * *=$ significant at $0.1 \%$; $\mathrm{NS}=$ not significant. In the full mediation empirical model, the relationship between University Environment and Entrepreneurial Intention is significant at $0.1 \%$, with a path coefficient value of 0.225

Figure 1. Complete empirical model 


\section{INMR 19,1}

\begin{tabular}{|c|c|c|}
\hline Hypotheses & Description & Result \\
\hline$H 1$ & $\begin{array}{l}\text { A supportive university environment for entrepreneurship has a } \\
\text { positive influence on undergraduate student's entrepreneurial } \\
\text { intentions }\end{array}$ & Confirmed \\
\hline H2 & $\begin{array}{l}\text { A supportive university environment for entrepreneurship has a } \\
\text { positive influence on undergraduate student's entrepreneurial } \\
\text { characteristics }\end{array}$ & Confirmed \\
\hline H3 & $\begin{array}{l}\text { Entrepreneurial Characteristics have a positive influence on } \\
\text { undergraduate student's entrepreneurial intention }\end{array}$ & Confirmed \\
\hline$H 4$ & $\begin{array}{l}\text { A supportive university environment for entrepreneurship, } \\
\text { entrepreneurial intention and entrepreneurial characteristics } \\
\text { differ in their relationship when considering distinct regional } \\
\text { ecosystems of innovation and entrepreneurship }\end{array}$ & Partially confirmed \\
\hline$H 4 a$ & $\begin{array}{l}\text { A supportive university environment for entrepreneurship and } \\
\text { entrepreneurial intention differ in its relationship when } \\
\text { considering distinct regional ecosystems of innovation and } \\
\text { entrepreneurship }\end{array}$ & Not confirmed \\
\hline$H 4 b$ & $\begin{array}{l}\text { A supportive university environment for entrepreneurship and } \\
\text { entrepreneurial characteristics differ in its relationship when } \\
\text { considering distinct regional ecosystems of innovation and } \\
\text { entrepreneurship }\end{array}$ & Not confirmed \\
\hline$H 4 c$ & $\begin{array}{l}\text { Entrepreneurial characteristics and entrepreneurial intention } \\
\text { differ in its relationship when considering distinct regional } \\
\text { ecosystems of innovation and entrepreneurship }\end{array}$ & Confirmed \\
\hline
\end{tabular}

Table 5

Summary of findings mediation effect, as seen similarly on Bignotti and Roux's (2016) study in South Africa. This investigation has the novelty of indicating that a supportive university environment influences entrepreneurial intention on BA students both directly and indirectly through entrepreneurial characteristics.

Considering the results gathered from both states, the following contributions can be drawn. First, even though university support has a positive influence on behavioral aspects, its four dimensions were not all positively assessed. Perceived concept development and perceived entrepreneurial characteristics development support have a positive impact on this result. Thus, the university environment prepares individuals to pursue this career by providing them with the necessary skills and capacities to undertake different kinds of challenges (Vodă \& Florea, 2019). On the other hand, perceived educational support and perceived business development support generated negative results. Thus, universities need to enhance their solutions on educational and business development to be a better influence on entrepreneurial intention and to be a source of trust, resources and inspiration to students (Asimakopoulos et al., 2019; Canever, Barral, \& Ribeiro, 2017).

Second, the relationship between entrepreneurial characteristics and entrepreneurial intention has been outlined. Students' intention to engage their business in the future is strongly influenced by their entrepreneurial characteristics, which presents a higher influence on entrepreneurial intention than the university environment, as seen similarly in Kusmintarti et al. (2014) for the case of Indonesian students. Taking a closer look, the mediation effect in the relationship between perceived university support for entrepreneurship and entrepreneurial intention illustrates the low influence of the university environment, which means that BA students enrolled at UEA, UNICAMP and USP do not necessarily intend to create new businesses. On the other hand, when combining the students' enrollment and characteristics, the intention is expected to arise. It can be 
postulated that entrepreneurial characteristics serve as a trigger to the positive effect of entrepreneurial intention.

Third, results indicate that broader ecosystems of innovation and entrepreneurship do not specifically affect the internal dynamics of universities when it comes to supporting entrepreneurial activity in students, i.e. the relationship of perceived university support for entrepreneurship with entrepreneurial intention or its relationship with entrepreneurial characteristics. Regarding entrepreneurial intention, there is no significant difference between Amazonas and São Paulo, which relates to the important and similar way of initially exposing students to entrepreneurship (Hayter et al., 2017; Wibowo et al., 2019). Concerning entrepreneurial characteristics, there is no significant difference between Amazonas and São Paulo, as well, indicating that UEA, UNICAMP and USP students benefit similarly from each university environment (Caliendo \& Kritikos, 2011). Both results related to entrepreneurial behavioral aspects can be explained by similar perceptions of interest among individuals, poor entrepreneurial culture in Brazil, the same regulatory environment for an entrepreneurial activity or Brazil's economic background (Fischer et al., 2019a; Landström \& Harirchi, 2018).

Finally, considering the different effects of ecosystem contexts in the relationship between entrepreneurial characteristics and entrepreneurial intention, a differential outcome was found, in which Amazonas displayed a stronger relationship for these variables than São Paulo. UEA students' characteristics work as a driver to entrepreneurial motivation, which, combined with certain conditions, can enhance the firm-formation process (Fischer et al., 2019a, 2019b). This result aligns with the Amazonas State Government's efforts to create and enforce a positive entrepreneurship ecosystem through its public policies. São Paulo also has initiatives to enforce entrepreneurship and ranks as the leading state in Endeavor's Entrepreneurial City Index. São Paulo also faces challenges because of its dimensions, such as culture (low entrepreneurship potential and perception) public policies (high taxes cost and complexity, as well as long-duration processes), which might be connected to the lower attractiveness of opening a new business in this state (Endeavor Brasil, 2017). Alternately, one has to recognize that this can be a function of the level of maturity between the analyzed ecosystems. While São Paulo offers a full-fledged array of employment opportunities for students, Amazonas has much more limited possibilities. In this case, constraints on innovation ecosystems can actually be a trigger for entrepreneurial behavior in academics. This raises the possibility of further inquiring into the relationship between innovation ecosystems' levels of maturity and the incentives for individuals to pursue a career in entrepreneurship.

Even though these findings do not fully support our hypotheses, they bring relevant insights for university management and entrepreneurship policy. As the academic environment can exert direct and indirect influences on entrepreneurial behavior and intentions in students regardless of the level of development of the ecosystems of entrepreneurship and innovation in which higher education institutions are located, then one might expect that universities can effectively play a pivotal role in shaping the conditions for entrepreneurial activity even in resource-constrained environments (Bedö, Erdős, \& Pittaway, 2020). This means that entrepreneurial universities can likely function as seedbeds for both strengthening successful ecosystems and setting in motion the entrepreneurial event in regions that lack complementary capabilities and agents. Hence, establishing an entrepreneurial orientation in universities can integrate these institutions with markets and boost their capacity of promoting regional development.

Universities represent an important determinant of entrepreneurial performance (Blasi \& Sedita, 2020). The main contribution of this investigation is to evidence the university environment role and collaborate with complementary reflections on evolving 
INMR

19,1

students entrepreneurship studies conducted in developing countries (Alves et al., 2019a; Moraes et al., 2020). This study also broadens the knowledge regarding the important factors that universities need to promote to foster entrepreneurship, according to students' perceptions. These aspects are key in the promotion of a more mature National System of Entrepreneurship in Brazil. While this country has been usually associated with high levels of Total Entrepreneurial Activity, this situation is mostly a function of new firms with low propensities to alter the aggregate competitiveness of the Brazilian economy. In turn, the promotion of entrepreneurship coming from academic settings is likely to upgrade the country's potential to produce new ventures that are innovationdriven (Alves et al., 2019a).

Considering the research gaps found, this investigation offers progress. First, a robust inquiry was developed and validated to assess the connections of perceived university support for entrepreneurship and behavioral aspects related to entrepreneurship. Second, the assessment tool offers different perspectives that could be part of Amazonas and São Paulo contexts. In addition, the model presented is comprehensive enough to be applied in different contexts and consider regional specificities. Third, we have added information on the dynamics of perceived university support for entrepreneurship in regional contexts, thus providing a set of evidence on these matters.

However, the appropriation of our conclusions to the broader spectrum of student entrepreneurs should be taken cautiously. As the sample comprises only BA students, the proximity of this academic cohort with the business environment and concepts might inflate the strength of relationships among analytical constructs when compared to students of other fields of knowledge. Also, students from all years were approached, therefore the maturation in students' perceptions might differ when considering first-year students and seniors.

Replicating the study with students from other fields and other universities, as well as including graduate students could enrich future analyzes on this topic. Further investigation can focus on students from a specific year of graduation to understand their perception on entrepreneurship. A longitudinal study could evaluate if the intention to start new businesses evolves to the business creation itself. Finally, an interesting avenue for future research on this topic would be to address sectoral and technological specificities of entrepreneurial activity emerging from universities and their level of relatedness with the orientation of ecosystems in which these institutions are embedded.

\section{Note}

1. Although the minimum required sample size for our empirical exercise is 109 , a larger sample $(N=$ 420) increases the statistical power of our estimations, allowing for more reliable assumptions about the significance of associations between analytical dimensions in our complete model. Additionally, to test if there were differences in the relationship of entrepreneurial intention, entrepreneurial characteristics and university environment ( $H 4$ and its sub-hypotheses), a minimum of 109 answers per state is necessary.

\section{References}

Abreu, M., \& Grinevich, V. (2013). The nature of academic entrepreneurship in the UK: Widening the focus on entrepreneurial activities. Research Policy, 42(2), 408-422. doi: 10.1016/j.respol.2012. 10.005 .

Acs, Z. J., Autio, E., \& Szerb, L. (2014). National systems of entrepreneurship: Measurement issues and policy implications. Research Policy, 43(3) doi: 10.1016/j.respol.2013.08.016.

Ajzen, I. (1991). The theory of planned behavior. Organizational Behavior and Human Decision Processes, 50(2), 179-211. doi: 10.1016/0749-5978(91)90020-T. 
Alves, A. C., Fischer, B. B., Schaeffer, P. R., \& Queiroz, S. (2019a). Determinants of student entrepreneurship an assessment. Innovation \& Management Review, 16(2), 2515-8961. doi: 10. 1108/INMR-02-2018-0002.

Alves, A. C., Fischer, B. B., Vonortas, N. S., \& Queiroz, S. R. R. D. (2019b). Configurações de Ecossistemas de Empreendedorismo Intensivo em Conhecimento. Revista de Administração de Empresas, 59(4), 242-257. doi: 10.1590/s0034-759020190403.

Asimakopoulos, G., Hernández, V., \& Peña Miguel, J. (2019). Entrepreneurial intention of engineering students: The role of social norms and entrepreneurial Self-Efficacy. Sustainability, 11(16), 4314. doi: 10.3390/su11164314.

Auerswald, P. E., \& Dani, L. (2017). The adaptive life cycle of entrepreneurial ecosystems: The biotechnology cluster. Small Business Economics, 49(1), 97-117. doi: 10.1007/s11187-0179869-3.

Barham, B. L., \& Coomes, O. T. (1994). Reinterpreting the amazon rubber boom: Investment, the state, and Dutch disease. Latin American Research Review, 29(2), 73-109.

Baron, R. M., \& Kenny, D. A. (1986). The Moderator-Mediator variable distinction in social psychological research. Conceptual, strategic, and statistical considerations. Journal of Personality and Social Psychology, 51(6) 1173. doi: 10.1037/0022-3514.51.6.1173.

Bedő, Z., Erdős, K., \& Pittaway, L. (2020). University-centred entrepreneurial ecosystems in resourceconstrained contexts. Journal of Small Business and Enterprise Development, 27(7). doi: 10.1108/ JSBED-02-2020-0060.

Bignotti, A., \& Le Roux, I. (2016). Unravelling the conundrum of entrepreneurial intentions, entrepreneurship education, and entrepreneurial characteristics. Acta Commercii, 16(1), 10 doi: 10.4102/ac.v16i1.352.

Blasi, S., \& Sedita, S. R. (2020). Determinantes and success factors of student entrepreneurship: Evidence from the University of Padova (No. 0260). Dipartimento di Scienze Economiche "Marco Fanno".

Brown, R., \& Mason, C. (2017). Looking inside the spiky bits: A critical review and conceptualisation of entrepreneurial ecosystems. Small Business Economics, 49(1), 11-30. doi: 10.1007/s11187-0179865-7.

Caliendo, M., \& Kritikos, A. (2011). Searching for the entrepreneurial personality: New evidence and avenues for further research. Journal of Economic Psychology, 33(2), 319-324. doi: 10.1016/j.joep. 2011.06.001.

Canever, M. D., Barral, M. R. M., \& Ribeiro, F. G. (2017). How does the public and private university environment affect students' entrepreneurial intention? Education + Training, 59, No. 6, 550-564. doi: 10.1108/ET-12-2016-0187.

Cavallo, A., Ghezzi, A., \& Balocco, R. (2019). Entrepreneurial ecosystem research: Present debates and future directions. International Entrepreneurship and Management Journal, 15(4), 1291-1321. doi: 10.1007/s11365-018-0526-3.

Chandler, A. D., \& Saxenian, A. (1995). Regional advantage: Culture and competition in Silicon Valley and route 128. The New England Quarterly, 68(1). doi: 10.2307/365972.

Chin, W., \& Newsted, P. (1999). Structural equation modeling analysis with small samples using partial least square. Statistical Strategies for Small Sample Research, 1(1), 307-341.

CNPq (2019). Mapa de Investimentos - Portal CNPq. Retrieved from http://cnpq.br/mapa-deinvestimentos-novo?p_auth=ZREnMD4U\&p_p_id=mapainvestimentoscnpqportlet_WAR_ mapainvestimentoscnpqportlet_INSTANCE_gXHn0VVSjQLc\&p_p_lifecycle $=1 \&$ p_p_ state $=$ normal\&p_p_mode $=$ view $\&$ p_p_col_id $=$ column $-1 \& p \_p \_c o l \_p o s=1 \& p \_p \_c o l \_$ count $=2 \& \_$mapainve.

Cohen, J. (1988). Statistical power analysis for the behavioral sciences (2nd edition). Hillsdale, NJ: Lawrence Erlbaum Associates. 
INMR

19,1

Davidsson, P. (2016). A "business researcher" view on opportunities for psychology in entrepreneurship research. Applied Psychology, 65(3), 628-636. doi: 10.1111/apps.12071.

De Noble, A. Jung, D., \& Ehrlich, S. (1999). Entrepreneurial self efficacy: The development of a measure and its relationship to entrepreneurial acttion. In Frontiers of Entrepreneurship Research.

Edwards, J. R., \& Lambert, L. S. (2007). Methods for integrating moderation and mediation: A general analytical framework using moderated path analysis. Psychological Methods, 12(1), 1-22. doi: 10. 1037/1082-989X.12.1.1.

Endeavor Brasil (2017). Índice de Cidades Empreendedoras. Retrieved from https://endeavor.org.br/ ambiente/indice-de-cidades-empreendedoras-2017/.

Faul, F., Erdfelder, E., Buchner, A., \& Lang, A. (2009). Statistical power analyses using G* Power 3.1. Behavior Research Methods, 41(4). doi: 10.3758/BRM.41.4.1149.

Fayolle, A., \& Liñán, F. (2014). The future of research on entrepreneurial intentions. Journal of Business Research, 67(5), 663-666. doi: 10.1016/j.jbusres.2013.11.024.

Fischer, B. B., Moraes, G. H. S. M. D., \& Schaeffer, P. R. (2019a). Universities' institutional settings and academic entrepreneurship: Notes from a developing country. Technological Forecasting and Social Change, 147, 243-252. doi: 10.1016/j.techfore.2019.07.009.

Fischer, B. B., Schaeffer, P. R., \& Queiroz, S. (2019b). High-growth entrepreneurship in a developing country: Regional systems or stochastic process? Contaduria y Administracion, 64(1), 1-23. https://doi.org/10.22201/fca.24488410e.2019.1816.

Godley, A., Morawetz, N., \& Soga, L. (2019). The complementarity perspective to the entrepreneurial ecosystem taxonomy. Small Business Economics, 56(2), 723-738. doi: 10.1007/s11187-01900197-y.

Hair, J. F., Hult, G. T. M., Ringle, C. M., \& Sarstedt, M. (2017). A primer on partial least squares structural equation modeling (PLS-SEM, Thousand Oaks, CA: SAGE Publications. https://doi. org/10.1080/1743727x.2015.1005806.

Hair, J., Sarstedt, M., Ringle, C. M., \& Gudergan, S. P. (2018). Advanced issues in partial least squares structural equation modeling, SAGE.

Hayter, C. S., Lubynsky, R., \& Maroulis, S. (2017). Who is the academic entrepreneur? The role of graduate students in the development of university spinoffs. The Journal of Technology Transfer, 42(6), 1237-1254. doi: 10.1007/s10961-016-9470-y.

Huyghe, A., Knockaert, M., \& Obschonka, M. (2016). Unraveling the "passion orchestra" in academia. Journal of Business Venturing, 31(3) doi: 10.1016/j.jbusvent.2016.03.002.

Ibarra, H., \& Obodaru, O. (2016). Betwixt and between identities: Liminal experience in contemporary careers. Research in Organizational Behavior, 36. doi: 10.1016/j.riob.2016.11.003.

IBGE (2018). Instituto Brasileiro de Geografia e Estatística - IBGE. Retrieved from https://cidades.ibge. gov.br/brasil/sp/sao-paulo/historico.

INEP (2017). Higher education Assessments - INEP. Retrieved from http://portal.inep.gov.br/web/ guest/higher-education-assessments.

Jena, R. K. (2020). Measuring the impact of business management student's attitude towards entrepreneurship education on entrepreneurial intention: A case study. Computers in Human Behavior, 107, 106275. doi: 10.1016/j.chb.2020.106275.

Klingbeil, C., Semrau, T., Ebers, M., \& Wilhelm, H. (2019). Logics, leaders, lab coats: A multi-level study on how institutional logics are linked to entrepreneurial intentions in academia. Journal of Management Studies, 56(5). doi: 10.1111/joms.12416.

Koe, W.L., Sa'ari, J. R., Majid, I. A., \& Ismail, K. (2012). Determinants of entrepreneurial intention among millennial generation. Procedia - Social and Behavioral Sciences, 40, 197-208. doi: 10. 1016/j.sbspro.2012.03.181. 
Krakauer, P. V. D C., Moraes, G. H. S. M., Coda, R., \& Berne, D. D F. (2018). Brazilian women's entrepreneurial profile and intention. International Journal of Gender and Entrepreneurship, 10(4), 361-380. doi: 10.1108/IJGE-04-2018-0032.

Kusmintarti, A. Thoyib, A. Ashar, K., \& Maskie, G. (2014). The relationships among entrepreneurial characteristics, entrepreneurial attitude, and entrepreneurial intention (vol. 16). Retrieved from www.iosrjournals.orgwww.iosrjournals.org.

Landström, H., \& Harirchi, G. (2018). "That's interesting!” In entrepreneurship research. Journal of Small Business Management, 1-23. https://doi.org/10.1111/jsbm.12500.

Liñán, F., \& Chen, Y.W. (2009). Development and Cross-Cultural application of a specific instrument to measure entrepreneurial intentions. Retrieved from https://journals.sagepub.com/doi/pdf/10. 1111/j.1540-6520.2009.00318.x.

Lüthje, C. L., \& Franke, N. (2003). The "making" of an entrepreneur: Testing a model of entrepreneurial intent among engineering students at MIT. R\&D Management, 33(2), 135-147. Retrieved from http://epub.wu.ac.at/4612/1/Luethje_Franke-2003-RDM_The-making-of-anentrepreneur.pdf doi: 10.1111/1467-9310.00288.

Mack, E., \& Mayer, H. (2016). The evolutionary dynamics of entrepreneurial ecosystems. Urban Studies, 53(10), 2118-2133. doi: 10.1177/0042098015586547.

Malerba, F., \& McKelvey, M. (2020). Knowledge-intensive innovative entrepreneurship integrating Schumpeter, evolutionary economics, and innovation systems. Small Business Economics, 54(2). doi: 10.1007/s11187-018-0060-2.

Markman, G. D., \& Baron, R. A. (2003). Person-entrepreneurship fit: Why some people are more successful as entrepreneurs than others. Human Resource Management Review, 13(2), 281-301. doi: 10.1016/S1053-4822(03)00018-4.

Mason, C., \& Brown, R. (2014). Entrepreneurial ecosystem and growth oriented entrepreneurship. Retrieved from https://www.oecd.org/cfe/leed/Entrepreneurial-ecosystems.pdf.

Matt, M., \& Schaeffer, V. (2018). Building entrepreneurial ecosystems conducive to student entrepreneurship: New challenges for universities. Journal of Innovation Economics, 25(1), 9-32. Retrieved from https://www.cairn.info/revue-of-innovation-economics-2018-1-page-9.htm doi: $10.3917 /$ jie.025.0009.

Miller, D., \& Acs, Z. J. (2017). The campus as entrepreneurial ecosystem: The university of Chicago. Small Business Economics, 49(1), 75-95. doi: 10.1007/s11187-017-9868-4.

Monitor, G. E. (2017). GEM 2016/2017 global report. Retrieved from https://www.gemconsortium.org/ report/gem-2016-2017-global-report.

Moraes, G. H. S. M., Iizuka, E. S., \& Pedro, M. (2018). Effects of entrepreneurial characteristics and university environment on entrepreneurial intention. Revista de Administração Contemporânea, 22(2), 226-248. doi: 10.1590/1982-7849rac2018170133.

Moraes, G. H. S. M., Fischer, B. B., Campos, M. L., \& Schaeffer, P. R. (2020). University ecosystems and the commitment of faculty members to support entrepreneurial activity. BAR - Brazilian Administration Review, 17(2), 1-26. doi: 10.1590/1807-7692bar2020190013.

Mustafa, M. J., Hernandez, E., Mahon, C., \& Chee, L. K. (2016). Entrepreneurial intentions of university students in an emerging economy: The influence of university support and proactive personality on students' entrepreneurial intention. Journal of Entrepreneurship in Emerging Economies, 8(2), 162-179. doi: 10.1108/JEEE-10-2015-0058.

Ozaralli, N., \& Rivenburgh, N. K. (2016). Entrepreneurial intention: Antecedents to entrepreneurial behavior in the U.S.A. and Turkey. Journal of Global Entrepreneurship Research, 6(1), 2-32. doi: 10.1186/s40497-016-0047-x.

Politis, D., Winborg, J., \& Dahlstrand, A. L. (2012). Exploring the resource logic of student entrepreneurs. International Small Business Journal: Researching Entrepreneurship, 30(6), pp. 659-683. doi: 10.1177/0266242610383445.

\section{Role of university environment}


INMR

19,1
Radosevic, S., \& Yoruk, E. (2013). Entrepreneurial propensity of innovation systems: Theory, methodology and evidence. Research Policy, 42(5). doi: 10.1016/j.respol.2013.01.011.

Ringle, C. M. Wende, S., \& Becker, J.M. (2015). How should I cite the use of SmartPLS?. SmartPLS 3. Bönningstedt: SmartPLS. Retrieved from: www.smartpls.com.

Rocha, E. L. D C., \& Freitas, A. A. F. (2014). Avaliação do Ensino de Empreendedorismo entre Estudantes Universitários por meio do Perfil Empreendedor. Revista de Administração Contemporânea, 18(4), 465-486. doi: 10.1590/1982-7849rac20141512.

Roundy, P. T. (2017). Small town" entrepreneurial ecosystems implications for developed and emerging economies. Journal of Entrepreneurship in Emerging Economies, 9(3), 238-262. doi: 10. 1108/JEEE-09-2016-0040.

Saeed, S., Yousafzai, S. Y., Yani-De-Soriano, M., \& Muffatto, M. (2015). The role of perceived university support in the formation of students' entrepreneurial intention. Journal of Small Business Management, 53(4), 1127-1145. doi: 10.1111/jsbm.12090.

Schaeffer, P. R., Fischer, B., \& Queiroz, S. (2018). Beyond education: The role of research universities in innovation ecosystems. Foresight and STI Governance, 12(2), 50-61. doi: 10.17323/2500-2597. 2018.2.50.61.

Schmidt, S., \& Bohnenberger, M. C. (2009). Perfil empreendedor e desempenho organizacional. Revista de Administração Contemporânea, 13(3), 450-467. doi: 10.1590/S1415-65552009000300007.

Schwarz, E. J., Almer-Jarz, D. A., \& Wdowiak, M. A. (2006). A structural model of entrepreneurial intent among students: findings from Austria. Diversity in Entrepreneurship, 29-43.

Secretaria da Fazenda e Planejamento - SP (2019). Repasses às Universidades. Retrieved from https:// portal.fazenda.sp.gov.br/acessoinformacao/Paginas/Repasses-para-Universidades.aspx.

SEDECTI (2018). SEDECTI. Retrieved from www.sedecti.am.gov.br/.

Sieger, P. Fueglistaller, U. Zellweger, T., \& Braun, I. (2018). Global student entrepreneurship 2018: Insights from 54 countries 2018 GUESSS global report. Retrieved from www.guesssurvey.org/ resources/PDF_InterReports/GUESSS_Global_2018.pdf.

Spigel, B. (2017). The relational organization of entrepreneurial ecosystems. Entrepreneurship: Theory and Practice, 41(1), 49-72.https://doi.org/10.1111/etap.12167.

Stam, E., \& van de Ven, A. (2019). Entrepreneurial ecosystem elements. Small Business Economics, 56(2), 809-832. doi: 10.1007/s11187-019-00270-6.

SUDAM (2020). Plano Regional de Desenvolvimento da Amazônia (PRDA): 2020-2023. Retrieved from www.sudam.gov.br.

Trivedi, R. (2016). Does university play significant role in shaping entrepreneurial intention? A crosscountry comparative analysis. Journal of Small Business and Enterprise Development, 23(3), 790-811. doi: 10.1108/JSBED-10-2015-0149.

Turker, D., \& Selcuk, S. S. (2009). Which factors affect entrepreneurial intention of university students? Journal of European Industrial Training, Vol. 33, No. 2, pp. 142-159. doi: 10.1108/ 03090590910939049.

UEA (2016). UEA - Universidade do Estado do Amazonas. Retrieved from www3.uea.edu.br/.

UNICAMP (2019). Anuário Estatístico - UNICAMP. Retrieved from https:/www.aeplan.unicamp.br/ anuario/anuario_2019.php.

USP (2019). Anuário Estatístico - USP. Retrieved from https://uspdigital.usp.br/anuario/ AnuarioControle.

Vodă, A., \& Florea, N. (2019). Impact of personality traits and entrepreneurship education on entrepreneurial intentions of business and engineering students. Sustainability, 11(4), 1192. doi: 10.3390/su11041192.

Wibowo, S. F., Purwana, D., Wibowo, A., \& Saptono, A. (2019). Determinants of entrepreneurial intention among millenium generation in emerging countries. International Journal of 
Entrepreneurship, 23(2), 1939-4675. Retrieved from https://www.abacademies.org/articles/ Determinants-of-Entrepreneurial-Intention-Among-Millennial-Generation-in-EmergingCountries-23-2-281.pdf.

Zhao, H., Hills, G. E., \& Seibert, S. E. (2005). The mediating role of self-efficacy in the development of entrepreneurial intentions. Journal of Applied Psychology, 90(6), 1265. doi: 10.1037/0021-9010.90. 6.1265 .

\section{Corresponding author}

Anne Kathleen Lopes da Rocha can be contacted at: anne.rocha@hotmail.com.br 